\title{
KELENDERIS BEŞIK TONOZLU MEZARLARI ÜZERİNE BİR DEĞERLENDİRME
}

\author{
Mevlüt ELIÜŞÜK¹
}

\begin{abstract}
ÖZ
Kelenderis antik kenti, Doğu Akdeniz dünyasında yer alan ve antik çağda Kilikya Bölgesi olarak adlandırılan bölgenin, Orta Dağlık bölümündeki önemli liman șehirlerinden birisidir. Tonozlu mezarlar kentin Batı ve Kuzey nekropollerinde görülmektedir. Tipolojik özelliklerine göre tek katlı ve iki katlı olarak iki ana grup altında değerlendirilen mezarların tek katlı örnekleri ön odalı ve tek odalı arkesollü olmak üzere iki alt gruba ayrılmıştır. Bölgede yapılan araştırmalarda Kelenderis'de tespit edilen ön odalı ve iki katlı mezarların en yakın benzerleri Anemurium, Antiocheia Cragum, Selinus, Iotepe, Syedra ve Ovabaşı nekropollerinde görülmektedir. Bu kentlerdeki benzer özellikteki tonozlu mezarlar, Anemurium örnekleriyle karșılaştırılarak M.S. II-III. yüzyıllar arasına tarihlenmiştir. Bu tarih aralığı Kelenderis örnekleri içinde geçerlidir. Kelenderis tek odalı arkesollü tonozlu mezarlarının ise bölgede herhangi bir benzer örneği tespit edilmemiş olup, bu tipin bölge için ünik olduğu anlaşılmıştır. Kelenderis tonozlu mezarlarının kendi içinde salt mimari özellikleri değerlendirildiğinde, sadece boş birer mezardan oluşmalarından dolayı, mezarlar içinde kronolojik sıralama yapılamamıştır. $\mathrm{Bu}$ durum gömü geleneği için de geçerlidir. Mezarlarda ölü kültü ile ilişskilendirebileceğimiz çok veri yoktur. Ancak kazılarda elde edilen ve kenti 19. yüzyılda gezen seyyahlardan elde edilen veriler ışığında mezarlara lahitlerle gömü yapıldığı anlaşılmıştır. Kelenderis Tonozlu Mezarları'nın Kilikya Bölgesi'ndeki diğer tonozlu mezarlara göre daha küçük ebatlı ve süslemesiz olmasını, o dönemde Kelenderis'in önemini ve gücünü kısmen kaybetmesiyle açıklamak mümkündür.
\end{abstract}

Anahtar Kelimeler: Kelenderis, Kilikya, Beşik Tonozlu Mezar.

\section{AN ASSESSMENT ON BARREL VAULTED TOMBS OF KELENDERIS}

\begin{abstract}
Kelenderis ancient city is one of the important harbors in Central Rough division of Cilicia Region in East Mediterranean world. Barrel vaulted tombs are placed in the West and North necropolies of the ancient city. These are investigated in two main groups in accordance with typological features;
\end{abstract}

\footnotetext{
${ }^{1}$ Arş. Gör., Batman Üniversitesi, Fen-Edebiyat Fakültesi, Kültür Varlıklarını Koruma ve Onarım Bölümü, Batman-TR, e-mail: mevluteliusuk@gmail.com.
} 
one floored and two floored. One floored tombs divided into two sub groups as single chamber with pronaos and single chamber with arcesolium. Researches in the region revealed that the most similar ones to the two floored type and single chamber with pronaos type tombs exist in Anemurium, Antiocheia ad Cragum, Selinus, Iotape, Syedra and Ovabaşı necropolises. Barrel vaulted tombs with similar features in these ancient cities are dated to A.D. $2^{\text {nd }}-3^{\text {rd }}$ centuries by comparison to Anemurium samples. This range of date is also applicable for Kelenderis samples. No other counterpart of the single chamber type tombs of Kelenderis with arcesolium has been detected, thus it can be said that this type is unique to the region. The architectural features of the tombs considered alone, it is not possible to make a chronological order as they consist solely of empty burial chambers. This is also relevant for burial customs. There is not much evidence that could be associated with burial cults. However, it has been discovered in light of the evidence obtained from archaeological excavations and descriptions of itinerants who visited the city in $19^{\text {th }}$ century that burials were made in sarcophagi placed into the tombs. It is possible to explain the fact that the Vaulted Tombs of Kelenderis are without ornaments and smaller than the other ones in Cilicia Region by the partial loss of city's prominence and power in the period.

Keywords: Kelenderis, Cilicia, Barrel Vaulted Tomb.

\section{Giriş}

Kelenderis $^{2}$ Dağlık Kilikya bölgesinin orta kesiminde bir liman kentidir (Zoroğlu, 2000a: 116) (fig.1). Antik kent bugünkü Mersin-Antalya karayolu üzerinde, Silifke ve Bozyazı ilçeleri arasında, Mersin'e bağlı olan Aydıncık ilçesinin nispeten eski olan bölümünde yer almaktadır. Kelenderis antik kenti ile ilgili, ilk kaynaklar kenti 17-19 yüzylda gezen seyyahlardan elde edilmektedir ${ }^{3}$. Bu seyyahlardan biri olan ve Kelenderis'deki tonozlu mezarlardan ilk kez M. Kinneir 1813-1814 yılında yaptığı gezilerde Kelenderis'den bahseder (kitabında kentin adını Kelendri olarak zikreder) ve tonozlu mezarların sayısını 20 kadar olduğunu, içlerinde ise lahitlerin bulunduğunu belirtir. Ayrıca bu mezarlardan ikisi üzerinde de yazıt bulunduğundan bahsetmektedir (Zoroğlu, 1994a: 27). Kelenderis ile ilgili ayrıntılı ilk bilimsel nitelikli yüzey araștırması R. Heberdy ve A. Wilhelm ekibi tarafından gerçekleștirilmiştir(Heberdy ve Wilhelm, 1896: 94-96; Zoroğlu, 1994: 29). Heberdy ve Wilhelm ekibi piramidal çatılı mezar anıtı ile tonozlu mezarlar hakkında oldukça ayrıntılı bilgi verirler.

\footnotetext{
2 Kelenderis adının kaynağı için bak. (Zoroğlu, 1994a: 8-13).

${ }^{3}$ Seyyahlar için bkz. (Zoroğlu, 1994a: 25-30).
} 
Kelenderis antik kentinden günümüze çok az sayıda kalıntı ulaşabilmiştir. Prof. Dr. L. Zoroğlu ${ }^{4}$ başkanlığındaki kazı çalışmaları ${ }^{5}$ 1987 yılından itibaren aralıksız devam etmektedir. Bu arkeolojik kazı ve araştırmalar sayesinde kentle ilgili oldukça önemli bilgiler elde edilmiştir. Kazılarda elde edilen veriler ışı̆̆ında; kent en parlak dönemini Klasik Çağ'da yaşamış daha sonraki devirlerde, bölgenin de içinde bulunduğu şartlara paralel olarak giderek önemini kaybetmesine rağmen hiçbir zaman tarih sahnesinde tümüyle yok olmamıștır (Tekocak, 2012: 306). Ayrıca kentin önemini yitirdiği bu dönemlerde bile eski parlak günlerine dönme çabası içerisinde olduğu bunda da zaman zaman başarıya ulaștığı anlaşılmaktadır. Kısacası Helenistik ve Roma dönemlerinde inişli ve çıkışlı günler yaşamasına karşın her durumda varlığını koruyabilmiştir ${ }^{6}$.

Kelenderis'de nekropollerde uzun süreden beri devam eden kazılar neticesinde mezar tipleri, ölü gömme adetleri ve mezar hediyeleri hakkında önemli bilgiler elde edilmiştir7. Ortaya çıkarılan nekropol alanlarında, çukur mezar, dromoslu yeraltı oda mezar, beşik tonozlu mezar, baldakenli mezar, lahit ve mezar stelleri olmak üzere altı farklı mezar tipi tespit edilmiştir (Zoroğlu, 2000a: 118.). Bizim çalışma konumuzu ise, mevcut mezar tiplerinden biri olan, beşik tonozlu mezarlar ${ }^{8}$ oluşturmaktadır ${ }^{9}$. Kentte yapılan

\footnotetext{
4 Yüksek lisans tezi kapsamında, Kelenderis örneklerini çalışma imkanı veren, danışman hocam Prof. Dr. K. Levent Zoroğlu'na yönlendirmeleri ve yardımları için teşekkür ederim.

${ }^{5}$ Kelenderis antik kenti kazıları için bkz. 1988-2014 yılı arasındaki Kazı Sonuçları Toplantıları.

6 Kelenderis antik kenti hakkında daha geniş bilgi için bkz. (Zoroğlu, 1994a: ; Zoroğlu, 1994b: 437-448; Zoroğlu, 1994c: 31-40; Zoroğlu, 1999: 513-519).

7 Kelenderis antik kenti nekropolleri ve nekropollerde bugüne kadar yapılan kazılarla, bu kazılarda ortaya çıkartılan mezar ve mezar buluntuları ile ilgili bkz. (Zoroğlu, 1986: 455-465; Zoroğlu, 1988: 409-411; Zoroğlu, 1989: 135-137; Zoroğlu, 1991: 302-307; Zoroğlu, 1994a: 32-45; Zoroğlu, 2000a: 115-133; Zoroğlu, Aslan ve Tekocak, 2000b: 135-137; Zoroğlu, Çalık-Ross, Tekocak ve Sağlan, 2004: 335-337; Zoroğlu ve Tekocak, 2008: 520-530).

${ }^{8}$ Genel bir tanımlamayla tonozlu mezar olarak adlandırılan bu tip verilen isimden de anlaşılacağı üzere üst örtüsü beşik tonoz şeklinde olan oda mezarlardır. (Machatscheck, 1967: 64 ve 74; ayrıca not 328; yazar burada Grabbauten ana başlı̆̆ altında tüm tonozlu mezarlar ve mezar evleri (Tonnenüberwölbte Graeber und Grabhaeuser) bir tip olarak ele almış, ayrıca Kilikya'da mezar yazıtlarında sıkça kullanılan Grekçe $\chi \alpha \mu \alpha ́ \rho \alpha$ (khamara) "üzeri tonozlu" sözcügünden hareketle bu gurubu aynı zamanda "oda" anlamına gelen "Kamara" olarak da tanımlamıștır; benzer bir değerlendirme için bkz: (Rosenbaum, 1971:1).
} 
çalışmalarda günümüze kadar 15 adet yer üstüne inşa edilen tonozlu mezar kalıntısı tespit edilmiştir (Zoroğlu, 2000a: 125). Bu 15 mezarın ne yazık ki beşinin büyük bir bölümü yok olmuştur. Bunların dışında önceki yıllarda tespit edilen iki örnekte de, mevcut halleriyle çalışmak mümkün olmamıştır. Bu nedenle, araştırmamızı çalışma imkânı bulabildiğimiz sekiz örnek üzerinden yapılacaktır. Her ne kadar 15 mezardan bahsetsek te, antik dönemde bu sayının daha da fazla olabileceği düşünülmektedir (Zoroğlu, 1994a: 27, dipnot.104). Çünkü Aydıncık ilçesi daha çok Silifke-Anamur Kara yolunun kuzey ve kuzeybatısındaki yamaçlarda gelişimini sürdürdügünden olasılıkla bu bölümlerdeki mezar yapıları tahrip edilmiş olmalıdır.

\section{Mezarların Konumu}

Kelenderis tonozlu mezarları kentin kuzey ve batısındaki yamaçlar üzerindeki dar teraslara inşa edilmişlerdir. Konumları itibariyle de nekropol alanları L. Zoroğlu tarafından Batı, Kuzey ve Doğu nekropolleri olarak adlandırılmıştır ${ }^{10}$ (fig.2). Batı Nekropolü olarak tanımlanan alan, antik kent yerleşim alanının batısında, MersinAntalya karayolunun kuzeyinde, bugünkü Aydıncık Çok Programlı Lisesi'nin doğu, batı ve güneyindeki alana yayılmış bölgedir. Mezarların büyük çoğunluğu, Lise binası ile karayolu arasındaki çam ağaçları ile kaplı fazla geniş olmayan bir alanda bulunmaktadır. Bu alanda kaya mezarları ve tonozlu mezarlar bulunmakla birlikte, tonozlu mezarlar batı nekropolünün daha çok kuzeyinde yani lise binasının doğusunda kalan alandadır. Burada birbirine yakın olarak inşa edilen üç tonozlu mezar yapısı vardır.

Kentin Kuzey Nekropolü ise bugünkü Mersin-Antalya karayolunun kuzeyinde kalan olarak tanımlamak mümkündür. $\mathrm{Bu}$ alanda baldaken tipli mezar anitı ve tonozlu mezarlar bulunmaktadır. Tonozlu mezarlar Aydıncık jandarma karakolunun hemen doğusunda Mersin-Antalya karayolunun hemen kenarındadır. Burada yan yana 7 tonozlu mezar tespit edilmiştir. Mezarların batıdan itibaren ilk beşinin büyük bölümü günümüze sağlam ulaşırken, en doğudaki iki örnekten sadece sırta duvarlarına ait kalıntılar kalmıştır. Ancak, bunlardan en doğuda kalan iki örneğin sadece sırt duvarlarına ait

\footnotetext{
${ }^{9} \mathrm{Bu}$ çalıșma yazarın, Selçuk Üniversitesi Sosyal Bilimler Enstitüsü Klasik Arkeoloji Anabilim Dalında Orta Dağlık Kilikya Bölgesi Kıyı Kesimi Tonozlu Mezar Mimarisi adlı Yüksek Lisans tezinden elde edilen veriler ıșığında geliştirilmiş bir çalışmadır.

10 Kelenderis nekropolünün sınırları için bak. (Zoroğlu, 1994a: 32-33; Zoroğlu, 2000a: 117-118)
}

28 | Celal Bayar Üniversitesi Sosyal Bilimler Dergisi - Cilt: 14, Sayı: 1, Mart 2016 
kalıntılar günümüze ulaşabilmiştir. Diğer mezarların ise büyük bir bölümü günümüze sağlam ulaşmıştır.

\section{Mezarların Tanımı ve Özellikleri}

Kelenderis'deki tonozlu mezar örnekleri plan ve tasarım açısından tek katlı ve iki katlı olmak üzere iki ana gurup altında değerlendirmek mümkündür. Tek katlı örnekler ise kendi içinde ön odalı arkesolsüz ve sadece mezar odasında oluşan arkesollü mezarlar olmak üzere iki tipte karşımıza çıkmaktadır. İki katlı tonozlu mezarlar ise tek bir örnekle temsil edilmektedir.

\subsection{Tek Katlı Örnekler}

Anıldığı üzere tek katlı mezarları, plan özelliklerine göre ön odalı, sadece mezar odasından oluşan arkesollü olmak üzere iki ana plan şemasına sahiptirler.

\subsection{1 Ön Odalı Tonozlu Mezarlar}

Tek katlı olarak sinıflandırdığımız bu mezarlar bir ön oda (pronaos) ve asıl mezar odası (naos) olmak üzere iki bölümden oluşmaktadır. Bu plan özelliğine sahip iki örnek batı nekropolündedir. Bu mezar tipinin en karakteristik özelliği bir ön odaya sahip olmasıdır. Plan şeması açısından temelde dikdörtgen planlı bir görünüm arz eden mezarların ön oda ile asıl mezar odası arasında bir perde duvarı inşa edilerek mezar iki ana bölüme ayrılır. Bu duvar TM.1 nolu mezarda (fig.3-4) günümüze sağlam ulaşırken, TM.2 nolu mezarın beşik tonozlu üst örtüsünün iç yüzeyinde (fig.5-6 perde duvarına ait izler kalmıştır. Perde duvarı ayakta kalan TM.1 nolu mezarda görülen mezar odası girişi duvarın ortasına gelecek şekilde konumlandırılmış olup, girişin üst bölümü ise yarım daire formlu bir kemere sahiptir (fig.3).

Bu iki mezarın mezar odalarının planları TM.1'de kare, TM.2'de ise dikdörtgen olduğu görülmektedir. Bu bağlamda iki örnekten yola çıkarak mezar odalarının planında bir standardın olmadığı anlaşılmıştır. Mezar odalarında ölü kültü ile ilişkilendirilebileceğimiz herhangi bir mimari unsur görülmemektedir.

Her iki mezarın ön odası açık şekilde günümüze ulaşmıştır. Ön odaların uzunlukları ve genişlikleri arasında farklılıklar görülürken, genel mimari özelliklerinin aynı olduğunu söylemek mümkündür. Mevcut halleri göz önüne alındığında TM.1 mezarında ön odanın üstü açıkken, TM.2'de kapalı olduğu görülmektedir. Bu bir ikilem yaratmış olsa da TM.1'in ön odasının büyük bir bölümü yıkılmış olduğundan olasılıkla buradaki ön odanın da TM.2'de olduğu gibi üst bölümünün kapalı olduğu anlaşılmaktadır. Ön odalarının cephelerinin açık ya da kapalı olduğuna dair kesin bir yargıda bulunmak oldukça zordur. Ancak bu plan özelliğine sahip en yakın sağlam örneklerin görülebildiği 
Anemurium ön odalı tonozlu mezarları değerlendirildiğinde, buradaki mezarların ön odalarının büyük bir bölümünün açık olduğu görülmektedir (fig. ${ }^{11}$ ). Olasılıkla Kelenderis örneklerinde de benzer şekilde ön odaların cephelerinin büyük bir bölümü açıtır.

E. Rosenbaum nekropol alanında yaptığı tasnifte ön odalı olan gurubu Tip 2 olarak değerlendirmiştir (Rosenbaum, 1971: 3, 9,92, lev.1). Burada E. Rosenbaum'un Anemurium örneklerinin de ön odalarının cephelerinin açık olduğunu belirtir ve bu alanın vestibulum (giriş holü) olarak değerlendirir (Rosenbaum, 1971: 3, 92). Anemurium örneklerinde bu bölümde nişler bulunmaktadır. Kelenderis örneklerinde ise niş bulunmamaktadır.

Ön odalı tonozlu mezarlar Dağlık Kilikya'da en yaygın tiplerden biridir. Dağllk Kilikya'da Antiochea Cragum (Rosenbaum-Huber ve Onurkan, 1967: 49-50), Selinus (Rosenbaum-Huber ve Onurkan, 1967: 53-58, 66), Iotepe ve Syedra (Rosenbaum-Huber ve Onurkan, 1967: 59, 66) ve Ovabaş̧ ${ }^{12}$ (Durugönül, 1998: 332; Durukan, 2001: 56) nekropollerinde görmek mümkündür. Bu mezarlar genel olarak M.S. IIIII yüzyllar arasına tarihlenmiştir (Rosenbaum-Huber ve Onurkan, 1967: 66; Durukan 2001, 56-57). Bölgede ön odalı tonozlu mezarların mezar odalarının bazılarında arkesol görülürken bir bölümünde ise arkesol bulunmaz. Bu da ön odalı Kelenderis örneklerinin Kilikya Bölgesi'yle uyum içinde olduğunu göstermektedir.

\subsubsection{Tek Odalı Arkesollü Tonozlu Mezarlar}

$\mathrm{Bu}$ tipi arkesollü olarak adlandırmamızın temel nedeni mezarların kuzey cephelerindeki üstü tonozlu nişlerdir. Arkesollü örneklerin tamamı kentin kuzey nekropolünde (fig.2)karşımıza çıkmaktadır. Mezarların bulunduğu alanda yedi tonozlu mezar tespit edilmekle birlikte bu mezarlardan sadece beși kısmen iyi durumdadır (fig.8).

$\mathrm{Bu}$ tipteki mezarların yan duvarları arkesolsüz örneklere göre daha kalındır. Genel olarak dikdörtgen plan şemasına sahip olan mezarların, içlerinde iki bölümden oluşan bir mezar odası bulunmaktadır. Mevcut hali ile ilk bölümlerinin ebatları 2,094,05x3,35-3,66 m ölçüleri arasında değişmekte olup dikdörtgen formludurlar (fig.9). İkinci bölüm, ilk bölümün gerisinde (kuzeyinde) ise yan ve üst örtüden $0,70 \mathrm{~m}$ kadar çıkıntı yaparak daha kalın ve daha alçak olarak inşa edilen üstü beşik tonozlu bölümdür. Bu bölüm mevcut hali ile bir arkesolu (arcesolium) andırmaktadır (fig.10). Buradaki

\footnotetext{
11 Mezarın kataloğu için bak. Rosenbaum 1971, 88, B.IV.II nolu mezar.

12 Kentin konumu için bak. Durukan, 2001, 52-53)
} 
arkesollerin derinlikleri 1,30-1,63 $\mathrm{m}$ arasında değişirken, arkesollerin uzunlukları ise 1,90-2,02 m arasındadır. Ölçülerden de anlaşılacağı üzere derinlik ebatlarında farklılık görülürken, bu nişli bölümlerin uzunluklarında bir tutarlığın olduğu anlaşılmaktadır.

Kuzey nekropolünde 2003 yllında yürütülen kazı çalışmalarında TM.513 (fig.9,11) nolu mezarın üst bölümündeki toprak tabakası temizlenerek yapının üst bölümü tamamen ortaya çıkarılmıştır. Bu çalışmada mezarın üst bölümünün iki kademeli olarak oluşturulduğu anlaşılmıştır. Burada güneyden itibaren 2,95 m'lik bölümün düz olduğu, devamında ise zeminden $0,55 \mathrm{~m}$ daha yükseltilmiş bir bölüm daha ortaya çıkarılmıştır. Bu alan 2,20 m uzunluğunda ve genişliği ise aynı zamanda mezarın genişliği olan 4,70 m'dir. Mezarın kuzey sırt duvarının ortaya çıkarılmasına yönelik yürütülen çalışmalarda ise, mezarın en üst bölümünden $0,55 \mathrm{~m}$ kadarlık bölümünün düz sonraki bölümlerinin ise gelişigüzel yerleştirilen moloz taşlar ile doldurulduğu anlaşılmıştır. Adeta bir podyum görüntüsünde olan bu alanın üst bölümünde yapılan kazılarda ise bu alanın moloz taş ve kireç harcı kullanılarak oluşturulduğu anlaşılmıştır (Zoroğlu, Çalık-Ross, Tekocak ve Sağlan, 2004: 336). Mezarın üst bölümünde bu kadar sağlam bir alanın varlığı ve işlevi hakkında kesin bir yargıda bulunmak oldukça zordur ancak bu kadar sağlam oluşturulan alan olasılıkla alttaki tonozlu mezar odasının taşıyabileceğinden daha ağır bir yükü taşımaya yönelik yapılmıştır. Bu nedenle bu alanı ölü kültü ile ilişkilendirmek gerektiğine inandığımı belirtmek isterim. Bu bağlamda bu alan bir lahit ya da lahitlerin yerleștirilmesi için oluşturulmuş olmalıdır. Ayrıca alttaki iki bölümlü tonozlu mezar odasının yan duvarlarının da oldukça kalın olarak inşa edilmiş olmasınıda, üst bölümdeki ağırlı̆̆ın taşınması için yapıldığıyla açıklayabiliriz.

Ayrıca yine TM.5'in zemin üstünde yapılan temizlik çalışmalarında yapının yan duvarlarının üst bölümünde ortaya çıkarılan harç izlerinden yola çıkarak mezarların iki katlı olabileceği düşünülmüştür (Zoroğlu, Çalık-Ross, Tekocak ve Sağlan, 2004: 336). Kazılarla elde edilen veriler dışında, TM.7 ve TM.8 mezarlarının, mezar odaları üzerinde de duvar kalıntıları görülmektedir (fig.8). Burada görülen duvar kalıntıları ve TM.5'deki duvar izlerinden elde edilen bilgilerden mezarların iki katlı olabileceği düşünülebilir. Ancak TM.7 ve

13 Kuzey nekropolünde çeşitli yıllarda temizlik çalışmaları yapılmıștır. Ancak kazı çalışmaları 2003 yılında V ve VI nolu mezarlarda yürütülmüștür, TM.5 olarak isimlendirdiğimiz mezar VI nolu mezar olarak isimlendirilmiștir (Zoroğlu, ÇalıkRoss, Tekocak ve Sağlan, 2004: 335-337). 
TM.8 mezarlarının üzerinde görülen duvar kalıntılarının, mezarların üzerinde yaklaşık 30 yıl öncesine kadar olduğu bilinen ve fotoğrafları da bulunan bir eve ait olduğu görülmektedir (fig.12). Ayrıca alttaki mezar odası ile belirtilen duvarlar arasında işçilik farkı olduğu da göze çarpmaktadır. Bu bağlamda TM.5'deki duvar izlerinide TM.7 ve TM.8 mezarlarında olduğu gibi buradaki başka bir evin varlığıla açıklamak mümkündür. Belirtilen sebeplerden dolayı Kelenderis Kuzey Nekropolü'ndeki tonozlu mezarların tek katlı olduğu anlaşılmıştır.

$\mathrm{Bu}$ guruba giren tonozlu mezarların mezar odalarının cephelerinin tamamı açıktır. Ancak TM.7 nolu mezarın, mezar odasının yan duvarlarında görülen duvar kalıntılarının varlı̆̆ı (fig.13) bu konuda bize önemli ipuçları sunmaktadır. Bu duvar kalıntıları belki de benzerini ön odalı örneklerde görüldüğü gibi benzer bir duvara ve girișe sahip olabileceğini akla getirmektedir.

Arkesollü gurubun plan özellikleri değerlendirildiğinde, Dağlık Kilikya'da özellikle kıyı kesiminde benzeri örnek bulunmamaktadır. Ayrıca bu plan şemasının benzeri bir örnek yaptığımız araştırmalarda Anadolu örneklerinde karşımıza çıkmamaktadır. Bu bağlamda bu tipin tonozlu mezar mimarisi için ünik bir örnek olduğunu belirtmemiz gerekmektedir.

\section{2. İki Katlı Tonozlu Mezar}

Kelenderis antik kentinde iki katlı olarak değerlendirebileceğimiz tek örnek Batı Nekropolündedir. TM.3 (fig.14) olarak adlandırdığımız bu mezardan günümüze; mezarın iki yan duvarı ile ikinci katın zeminin taşıyıcı tonoz çıkıntıları ulaşmıştır. Mevcut izlerden mezarın alt katının üst örtüsünün beșik tonozlu olduğu anlaşılmaktadır. Olasılıkla tek katlı ön odalı örneklerde olduğu gibi bu mezarın da birinci katının üst bölümü düz dam şeklinde olmalıdır. Yapının ikinci katının üst örtüsüne dair herhangi bir ipucu günümüze ulaşmamıștır. Ancak altta olduğu gibi olasılıkla burada da beșik tonozlu, bir üst örtü olmalıdır.

İki katlı tonozlu mezarlara Kilikya Bölgesi'nde Anemurium ve Ovabaşı nekropollerinde görülmektedir. Anemurium örneklerinde alttaki tonozlu mezar odası ile üstteki tonozlu mezar odaları birbirine dik yerleștirilmiştir. Alt mezar odalarında arkesoller bulunurken üst kat boş bir odadan ibarettir. Ovabaşı Nekropolü'nde ise alt ve üst kat birbiriyle aynı yöndedir. Burada mezarın ikinci katı iki bölümden oluşmakta ve ilk bölüm diğerine göre daha küçük oluşturulmuştur. $\mathrm{Bu}$ iki bölüm arasındaki bağlantı küçük, üst bölümü kemerli bir açıklıkla sağlanmaktadır (Durukan 2001: 54). Ovabaşı Nekropolün'deki iki katlı mezarların, birinci katının dikdörtgen planlı tek odal, ikinci katın ise iki 
$\overline{\text { odadan oluşmaları, Kelenderis Batı Nekropolü'nde ön odalı ve iki katlı }}$ tonozlu mezarların aynı alanda birbirine çok yakın bir şekilde inşa edilmelerini açıklamaktadır. Bu verilerin ışığında Kelenderis Batı Nekropolü'nde ön odalı ve iki katlı örneklerin hemen hemen aynı mezar tipinin özelliklerini barındırdığı anlaşılmıştır.

\subsection{Kullanılan Malzeme}

Tonozlu mezarların yamaçlarda, burada var olan veya yapay olarak oluşturulan küçük teraslarda inşa edilmişlerdir. Bunlardan kiminin zemini kaya olduğundan, yontularak düz bir zemin elde edilmeye çalışılmıştır. Toprak zeminlere inşa edilen kimi mezarların duvarları ise, derinliği 0.20-0.30 m'yi geçmeyen temellerin üzerine inşa edilmiştir. Duvar örgüsünde genellikle moloz taşların kullanıldığı yapılarda köşelerde yarı işlenmiş taşların kullanıldığı görülmektedir. Yapıların tonozlarında ise kalınlıkları 0,10-0,25 m arasında değișen kayrak taşlar kullanılmıștır.

\section{3. Ölü Gömme Geleneği}

Genel olarak yukarıda da değinildiği üzere tonozlu mezarlara gömünün nasıl konduğuyla ilgili veriler oldukça sınırlıdır. Pek çoğu yıkılmış, sağlam olan örneklerin ise soyulmuş ya da birkaç kullanım geçirmiş olmalarından dolayı mezarlar boş birer odadan ibarettir. $\mathrm{Bu}$ nedenle kazılar sırasında elde edilen sınırlı veriler ışığında, mezarlara gömünün nasıl yapıldığına dair önerilerde bulunabiliriz.

Yukarıda belirttiğimiz üzere tonozlu mezarlarda arkesollu gurup dışında herhangi bir özel alan bulunmamaktadır. Kentte yürütülen arkeolojik kazılarda, Batı Nekropolü'nde TM.1 nolu mezarda yapılan temizlik çalışmalarında mezar odasında bir lahit kapağı parçası bulunmuştur (Zoroğlu, 1987: 110, Res.4-5). Bunun dışında Kuzey Nekropolü'ndeki arkesollu olarak adlandırdığımız tonozlu mezarların birinin yanında iki mermer lahit kapağı bulunmaktadır. Lahit kapaklarının bu mezarlara ait olup olmadığı konusunda bir yorum yapmak oldukça zordur. Bu lahit kapakları yol inşası sırasında ortaya çıkmış olabilir. Ancak büyük bir tonozlu mezar gurubunun burada olması göz önüne alındığında bu lahit kapaklarını tonozlu mezarlarla ilişkilendirmemize neden olmaktadır. .

$\mathrm{Bu}$ iki somut veri dişında, M. Kinneir'in 1913-1814 yılları arasında Anadolu'ya yaptığı gezilerde Kelenderis'de 20 kadar tonozlu mezar ve bunların içindeki lahitlerden söz etmesi, tonozlu mezarlara, lahit içinde gömü yapıldığını kanıtlayan önemli bir veridir (Zoroğlu, 1994: 27). Belirtilen bilgiler ıșığında tonozlu mezarlarda lahit gömü yapıldığını söylemek mümkündür. Kelenderis'de lahit gömülerin varlığının bilinmesine rağmen neden bu kadar az lahit günümüze 
ulaştığıyla sorusunun cevabının Kelenderis agora kazılarında ortaya çıkarılan kireç ocaklarının (Zoroğlu ve Tekocak, 2008: 533, Res.1.) olacağı kanaatindeyim. Çünkü burada ocak çevresinde parçalanmış mermer parçalarının varlığı olasılıkla kentteki mermer kalıntıların birçoğunun bu tip kireç ocaklarında yakıldığını göstermektedir. Değinilen iki lahit kapağı dışında TM.5 mezarında tespit edilen yükseltilmiş bölümün varlığı, mezarın üst bölümünde, bu kalın duvar üzerine bir lahtin yerleştirilmiş olabileceğini açıklamaktadır. Her ne kadar mezarlara lahit içinde gömü yapıldığını ileri sürsek de belki de Anemurium'da E. Rosenbaum tarafından ileri sürülen kolay bozulabilen malzemeden inşa edilen lahitlerin de kullanılmış olabileceği gözden kaçırılmamalıdır.

Yukarıda da değinildiği üzere tek odalı arkesollü ve iki katlı tonozlu mezarların alt ve üst bölümlerinin gömü geleneği içinde kullanılmıştır. Bu bağlamda mezarların alt ve üst bölümlerine kim yada kimlerin gömülmüş olabileceği sorusu ortaya çıkmaktadır. Bu sorunun cevabı için, J. Borchardt'ın Myra ve çevresinde yaptı̆̆ çalışmalarda, iki katlı mezarlarda alttaki mezar odasının varisler, torunlar, Threptoi(evlatlık çocuklar) ya da aynı soydan gelenlere, üstteki mezar odalarının ise özel olarak mezarın birincil sahiplerine ayrıldığını belirtmesi önemli bir ipucudur (Borchardt, 1993: 7-22). J. Borchardt'ın çalışma yaptığı ve altta kimin gömüleceğine dair önerilere örnek olarak, Antiphellos'daki Maxzza Mezar Anıtı'nda ele geçen yazıtta; mezarın üst bölümüne sadece Ida Maxzza ve eşinin gömülebileceği ve onların üzerine kimsenin gömülemeyeceği ve eğer gömülürlerse de tanrılar ve Likya'nın 'itlehi14' tarafından cezalandırılacakları belirtilmektedir (Borchardt, 1993: 12). J. Borchardt'ın incelediği her iki mezar anıtı değerlendirildiğinde mezarın üst bölümünün statü bakımından daha üstün olduğu anlaşılmaktadır.

Roma Dönemi'ne tarihlenen her iki mezardan da anlaşıldığı üzere mezar içerisinde üst kata gömülme, yüksek statü anlamına gelmektedir. Anılan tonozlu mezarlar içinde bu durum söz konusu olmalıdır. Mezarların alt bölümlerinin bir çeşit hyposorion olarak düşünülmüş olmalıdır. Tek katlı olan ve üstte bir lahtin yerleștirilmiş olduğunu ileri sürdüğümüz tek odalı arkeosollü örneklerde de bu durum geçerli olmalıdır. Alttaki mezar odasına ikinci derecede akrabalar ya da mezar sahibinin eşi ve kendisi dişında kalan kişi ya da kişiler gömülmüş olmalıdır. Üstte ise özellikle TM.5 nolu mezarda

\footnotetext{
14 İtlehi teriminin karșılığı olarak herhangi bir bilgi verilmemiștir.
} 
tespit edilen yükseltilmiş alana mezar sahibinin kendisi ya da birinci derece akrabaları gömülmüş olmalıdır. İki katlı tonozlu mezarda üst kata ulaşımı sağlayan herhangi bir mimari öğenin olmayışı, üst katı ulaşılamaz hale getirmekte ve böylelikle hayatta olanlar için, üst katın anma ritüellerinde kullanılma ihtimalini düşürmektedir. $\mathrm{Bu}$ nedenle tek katlı arkesollü tonozlu mezarlar için önerilen alt ve üst bölümün kullanım şekli için önerimiz bu mezar tipi için de geçerlidir.

Genel olarak toparlayacak olursak eldeki verilerin yetersizliği nedeniyle tonozlu mezarlara nasıl gömü yapıldığı ile ilgili olarak yorum yapmak oldukça güçtür. Sadece yukarıda belirtilen verilerin ışığında tonozlu mezarlarda lahit yerleștirilerek gömü yapılmış olabileceğini ve lahitlerin konumunun mezar sahiplerinin statüleriyle ilişkili olabileceğini söylemek mümkündür.

\subsection{Mezarların Tarihi}

Kelenderis örneklerinde yukarıda da belirtildiği üzere sadece boş mezar odalarından ibaret olduğundan mezarların tarihlenmesi, benzer örneklerden yola çıkarak yapılabilmektedir. Bu bağlamda Kelenderis beşik tonozlu mezarlarının en yakın örneklerinin bulunduğu Anemurium'da en erken tip olarak değerlendirilen ve basit bir odadan oluşan yüksek tonozlu mezarların M.S. I. yüzyılın ikinci ve üçüncü çeyreğinde inșa edilmeye başlandığı ve M.S. II yüzylda bunların inşaatlarının sürdüğü belirtilmiştir (Rosenbaum, 1971: 30-31). Kelenderis'de bu erken tipe benzeyen bir örnek bulunmamaktadır. Kelenderis'de tespit edilen üç mezar tipinden sadece ön odalı ve iki katlı mezarların Kilikya Bölgesi'nde benzerleri bulunmaktadır. Bu grup A. Rosenbaum tarafindan tip 2 olarak adlandırılmıştır. Bu mezar tipinin yakın benzerleri Antiochea Cragum (Rosenbaum-Huber ve Onurkan, 1967: 49-50), Selinus (Rosenbaum-Huber ve Onurkan, 1967: 53-58, 66), Iotepe ve Syedra (Rosenbaum-Huber ve Onurkan, 1967: 59, 66) ve Ovabașı (Durugönül, 1998: 332; Durukan, 2001: 56) nekropollerinde karşımıza çıkmaktadır. Bu örneklerin tamamı Anemurium Nekropolü örnekleriyle karşılaştırılarak M.S. II-III yüzyıllar arasına tarihlenmiştir. Bu bağlamda Kelenderis tonozlu mezarlarını da bu tarih aralığında inşa edilmiş olduklarını söylemek mümkündür.

\section{Değerlendirme ve Sonuç}

Genel olarak Kelenderis tonozlu mezar anıtlarının; tek katlı ve ön odalı, tek odalı arkesollü ve iki katlı olmak üzere üç farklı tiptedir. Burada 8 örnek üzerinde yaptığımız çalışmada mezarlarda kullanılan malzemenin aynı olduğu ve mezarların inşa dönemlerinin de aşağı yukarı aynı tarih aralığında olduğu anlaşılmıştır. Tipolojik farklılıklara rağmen mezarlara lahitler ile gömü yapılmış olma 
ihtimalinin oldukça yüksek olduğunu söyleyebiliriz. Yukarıda da değinildiği üzere mezarlar mimari özelliklerine göre sınıflandırılmıştır. Ancak yaptığımız bu sınıflandırmada belirtilen guruplar arasında sadece mezar yapılarından yola çıkarak kronolojik sınıflandırma yapmanın mümkün olmadığı anlaşılmıştır.

Mezarların mimari özellikleri ve ebatları göz önüne alındığında, mezarların bir aile mezarı niteliğinde olduğu anlaşılmaktadır. Her ne kadar ölü kültü ile bağdaştırabileceğimiz çok fazla veri olmamasına rağmen, farklı tiplerde büyük ebatlı mezarların varlığını ancak bu şekilde açıklayabiliriz. Ayrıca şunu belirtmek gerekir ki Kelenderis'de daha önceki dönemlerde kullanılan ve kısmen Roma döneminde de az da olsa kullanıldığ bilinen aile mezarı şeklinde yer altı dromoslu kaya mezarlarının varlığı, aile mezarı geleneğinin (Tekocak, 2012: 308; Zoroğlu ve Tekocak, 2007: 520-530) Kelenderis için çok daha eski dönemlere gittiğini göstermektedir. Bu bağlamda tonozlu mezarlarda da bu geleneğin halen devam ettiğini söylemek mümkündür.

Mezarların inşa dönemi olarak belirttiğimiz M.S. II-III yüzyıllar göz önüne alındığında bu tarih aralığının, Anadolu'da Hadrian'la başlayan yoğun imar faaliyetlerinin, Antoninler ve Severuslar Dönemi'nde de devam ettiği tarih aralığı ile hemen hemen aynı olduğu görülmektedir (Erdem, 1995: 17). Özellikle M.S. II yüzyılın sonu ve III. yüzyllın başlarında yani Severuslar Dönemi'nde Kilikya Bölgesi'nde imar hareketliliği, altın çağını yaşamıştır (Kaplan, 2011: 111). Bu durumu Septimius Severus Dönemi'nden itibaren artan Parth seferleri dolayısıyla sinıra yakın eyaletlerden biri olmasından ve Suriye'ye geçişi sağlayan geçitleri ve yolları bünyesinde barındıran stratejik konumundan dolayı olmalıdır. Kentte belirtilen tarih aralığında şu an için 15 olan tonozlu mezar örneğinin belki de o dönemde çok daha fazla olması muhtemeldir. Kelenderis tonozlu mezarlarının yakın çevresindeki Anemurium ve Elaiussa Sebaste örneklerinden çok daha küçük ebatlı olmasının yanında süsleme unsurlarının bulunmamasını Kelenderis'in o dönemde bir liman kenti olarak Anemurium ve Elaiussa Sebaste gibi büyük liman kentlerinin gölgesinde kalmasıyla açıklayabiliriz.

\section{KAYNAKLAR}

BORCHARDT, J. (1993), "Die obere und untere Grabkammer, Beobachtungen $\mathrm{zu}$ den Bestattungsbräuchen der lykischen Oberschicht", in M.Kubelik and M.Schwarz, eds. Von der Bauforschung zur Denkmalpflege, Festschrift für Alois Machatschek 
zum 65. Geburtstag, Viyana, 1993, 7-22.

DURUKAN, M. (2001), Dağlık Kilikia Mezarları ve Ölü Kültü, (Yayımlanmamış Doktora Tezi), İzmir, Ege Üniversitesi.

DURUGÖNÜL, S. (1998), “1997 Yılı İçel İli (Antik Dağlık Kilikya) Yüzey Araştırması, AST, 16, cilt I, Ankara, 329-337.

ERDEM, Z.K. (1996), Anadolu'da Hadrianus Dönemi Mimari Bezemeleri, (Yayımlanmamış Doktora Tezi)İstanbul, İstanbul Üniversitesi.

HEBERDY, R. ve WİLHELM, K. (1896), Reisen in Kilikien, Wien.

KAPLAN, D. (2011), “Doğu Dağlık Kilikia'da İmar Hareketliliğinin ve Üretim Artışının Nedenleri”, Türkiye Bilimler Akademisi Arkeoloji Dergisi, 14, 107-120.

MACHATSCHEK, A. (1967), Die Nekropolen und Grabmäler im Gebiet von Elaiussa-Sebaste und Korykos im Rauhen Kilikien, Wien.

ROSENBAUM, E.A; HUBER, E. ve ONURKAN, S., (1967), $A$ Survey of Coastal Cities in Western Cilicia, Ankara.

ROSENBAUM, E.A. (1971), Anamur Nekropolü (The Necropolis of Anemurium), TTK, Ankara.

TEKOCAK, M. (2012), "Kelenderis Batı Nekropolünden Bir Mezarın Buluntuları Üzerine Değerlendirmeler", Selçuk Üniversitesi Sosyal Bilimler Enstitüsü Dergisi, Sayı.27, 305-315.

ZOROĞLU, L. (1986), “Kelenderis Mezar Buluntuları”, Anadolu Araştırmaları $X, 455-465$.

ZOROĞLU, L. (1988), "Kelenderis 1986 Yılı Çalışmaları”, AST, 5, cilt.I, Ankara, 409-422.

ZOROĞLU, L. (1989), "Kelenderis 1987 Yılı Kazısı", KST, 10, cilt I, Ankara, 135-155.

ZOROĞLU, L. (1991), "Kelenderis 1989 Yılı Kazısı", KST, 12, cilt II, Ankara, 301-322.

ZOROĞLU, L. (1994a), Kelenderis I, Kaynaklar Kalıntılar Buluntular, Ankara.

ZOROĞLU, L. ( 1994b), “Kelenderis'in İlk Çağ Tarihi Hakkında Notlar", TTKY 9, 437-448.

ZOROĞLU, L. (1994c), "Bir Mozaik Üzerinde Kelenderis Betimlemesi”, 1993 Yılı Anadolu Medeniyetleri Müzesi Konferansları, 31-45.

ZOROĞLU, L. (1999). "Kelenderis Mozaiği”, Çağlar Boyunca Anadolu'da Yerleşim ve Konut Uluslararası Sempozyumu, İstanbul, 5-7 Haziran 1996, 513-524.

ZOROĞLU, L. (2000a), “Kelenderis Nekropolü”, Olba III, 115133. 
ZOROĞLU, L., ASLAN, N. ve TEKOCAK, M. (2000b), "1998 Yılı Kelenderis Kazı Çalışmaları" KST, 22, cilt II, Ankara, 311-324. ZOROĞLU, L., ÇALIK-ROSS, A., TEKOCAK, M. ve SAĞLAN, S. (2004), "Kelenderis 2003 Yılı Kazısı Raporu", KST, 26, cilt I, Ankara, 333-346.

ZOROĞLU, L. ve TEKOCAK, M. (2007), "Kelenderis 2006 Yılı Çalışmaları", KST, 29, cilt I, Ankara, 515-538. 
Kelenderis Beşik Tonozlu Mezarları Üzerine Bir Değerlendirme

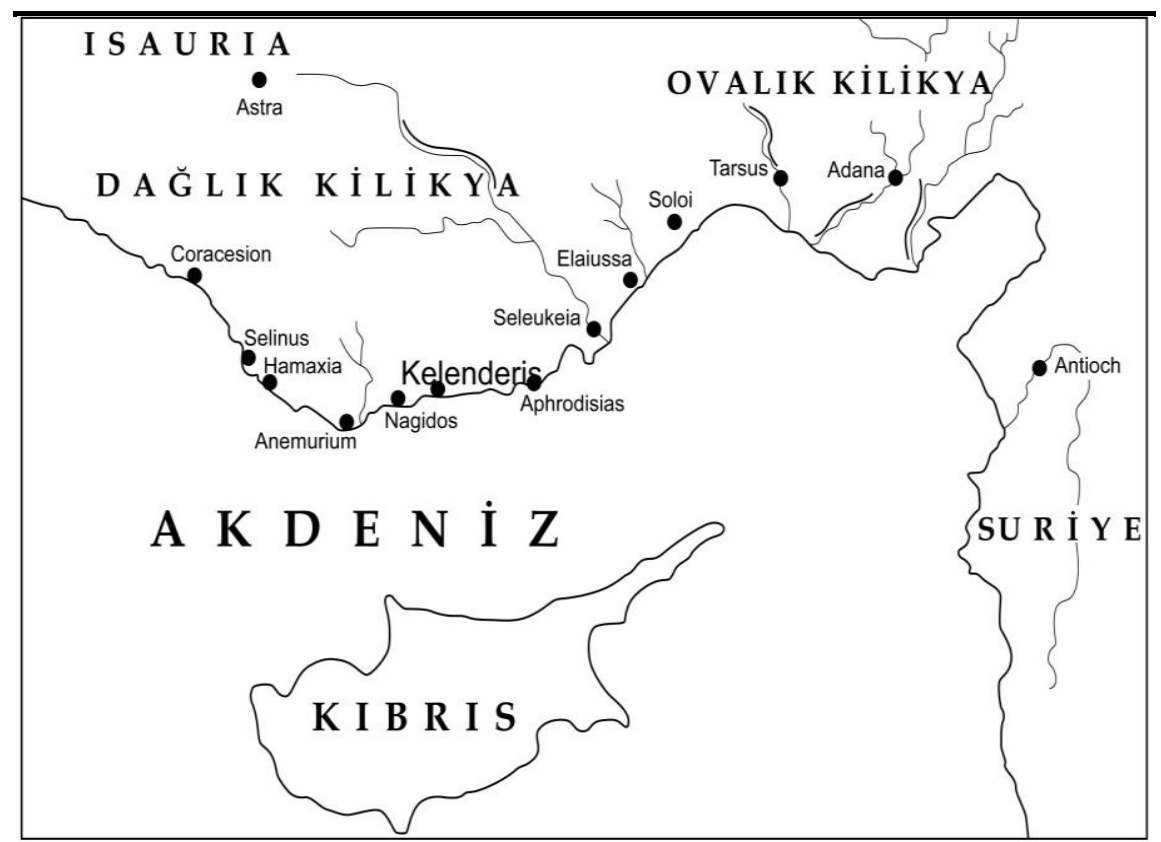

Fig.1; Kilikya Bölgesi ve Kelenderis'in Konumu

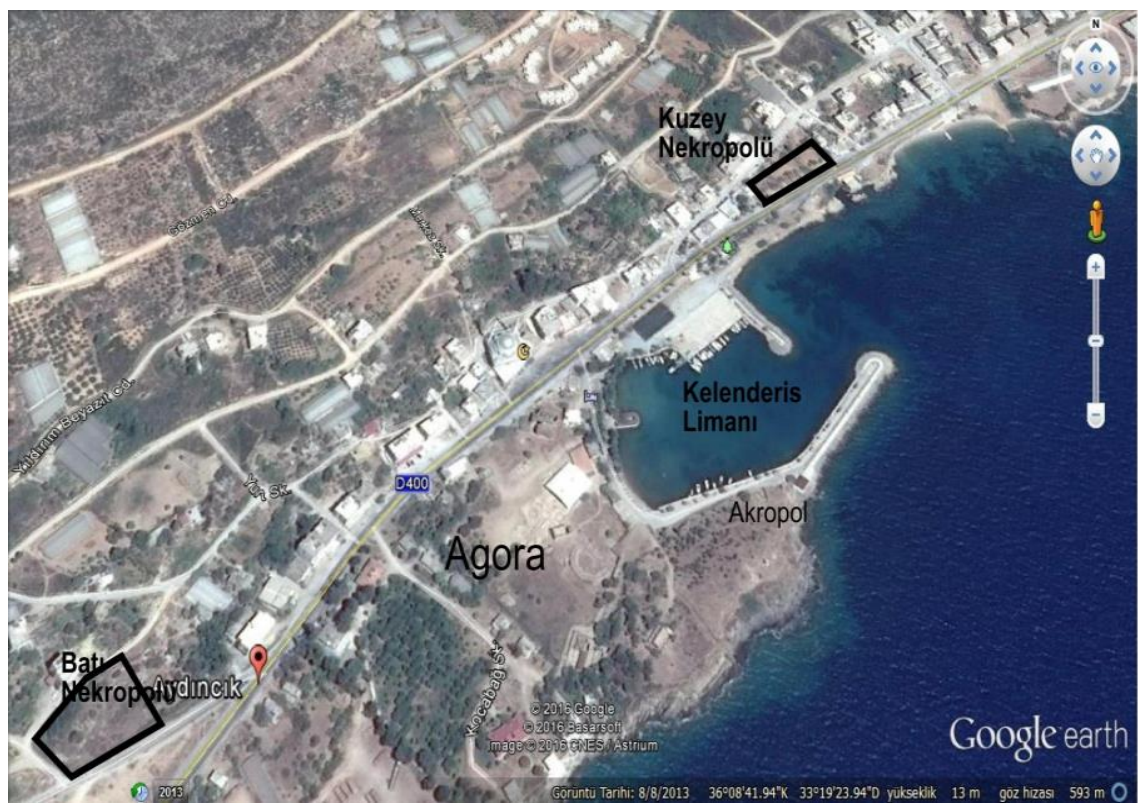

Fig.2; Kelenderis Antik Kenti Nekropol Alanları 


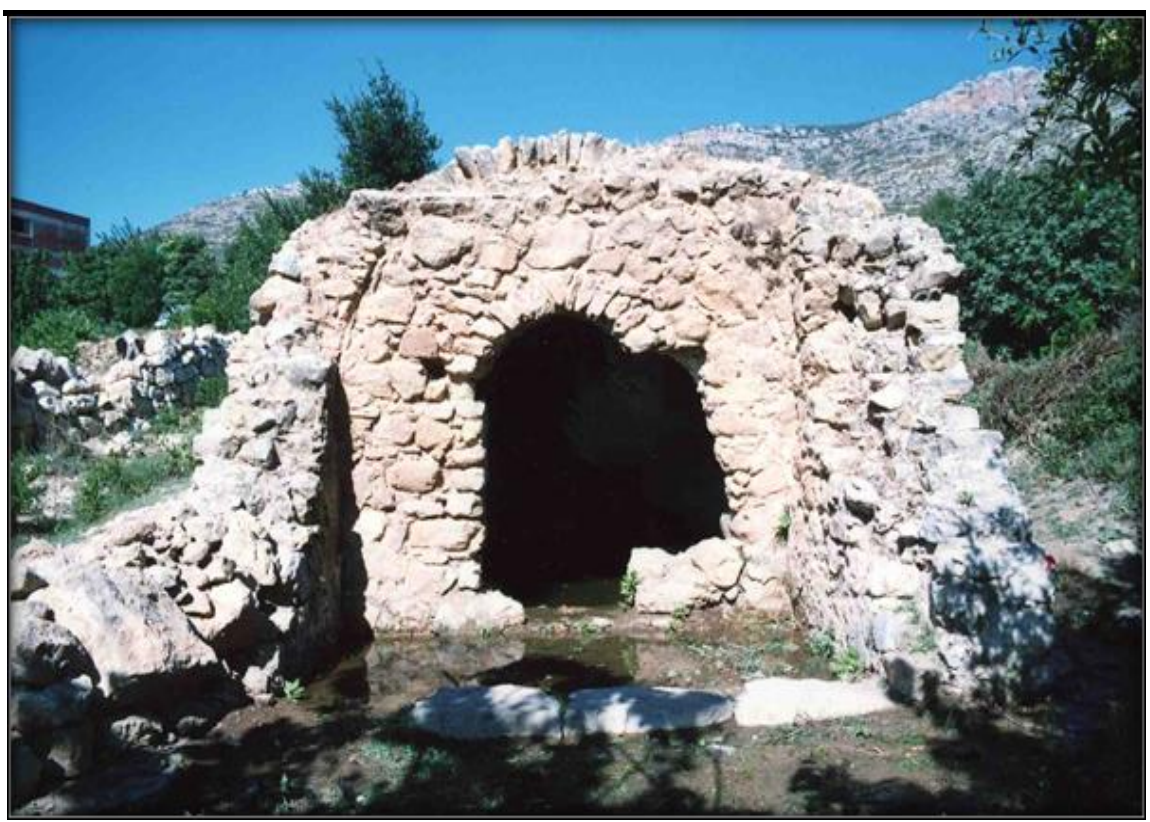

Fig.3; Kelenderis TM.1

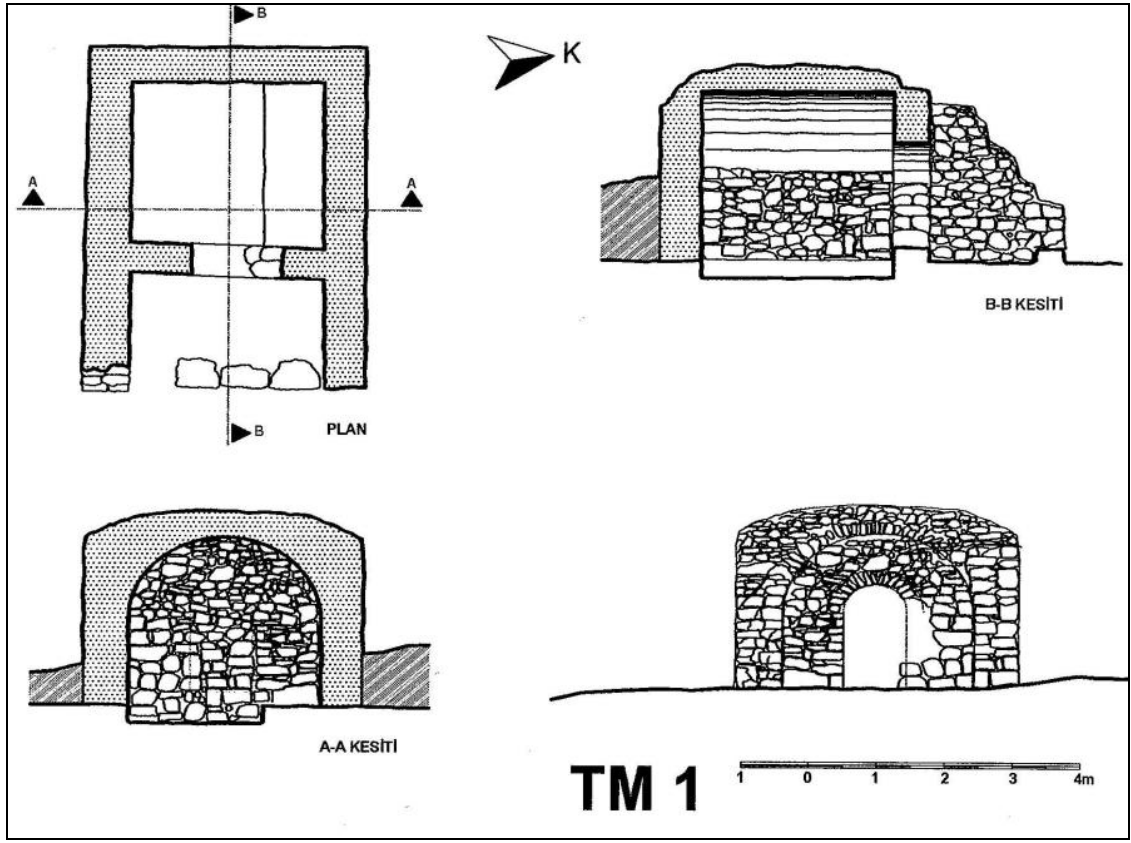

Fig.4; TM.1 Nolu Mezar Kesit, Plan ve Görünüş Çizimi 


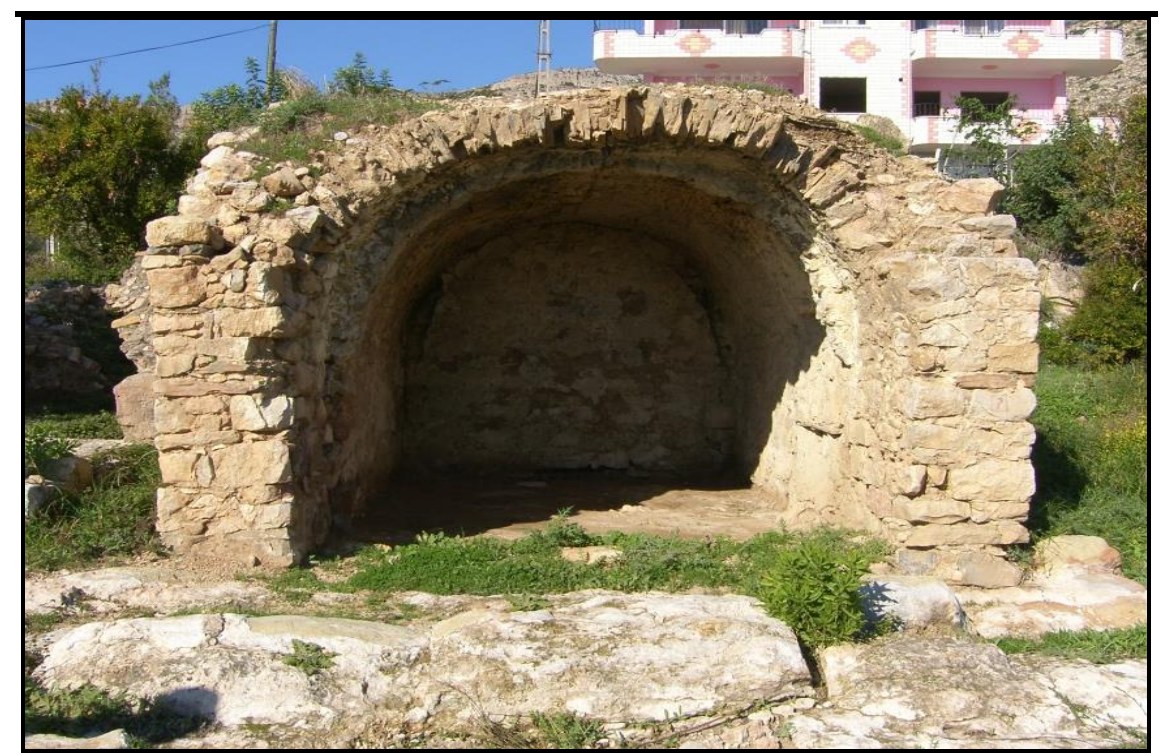

Fig.5; TM 2

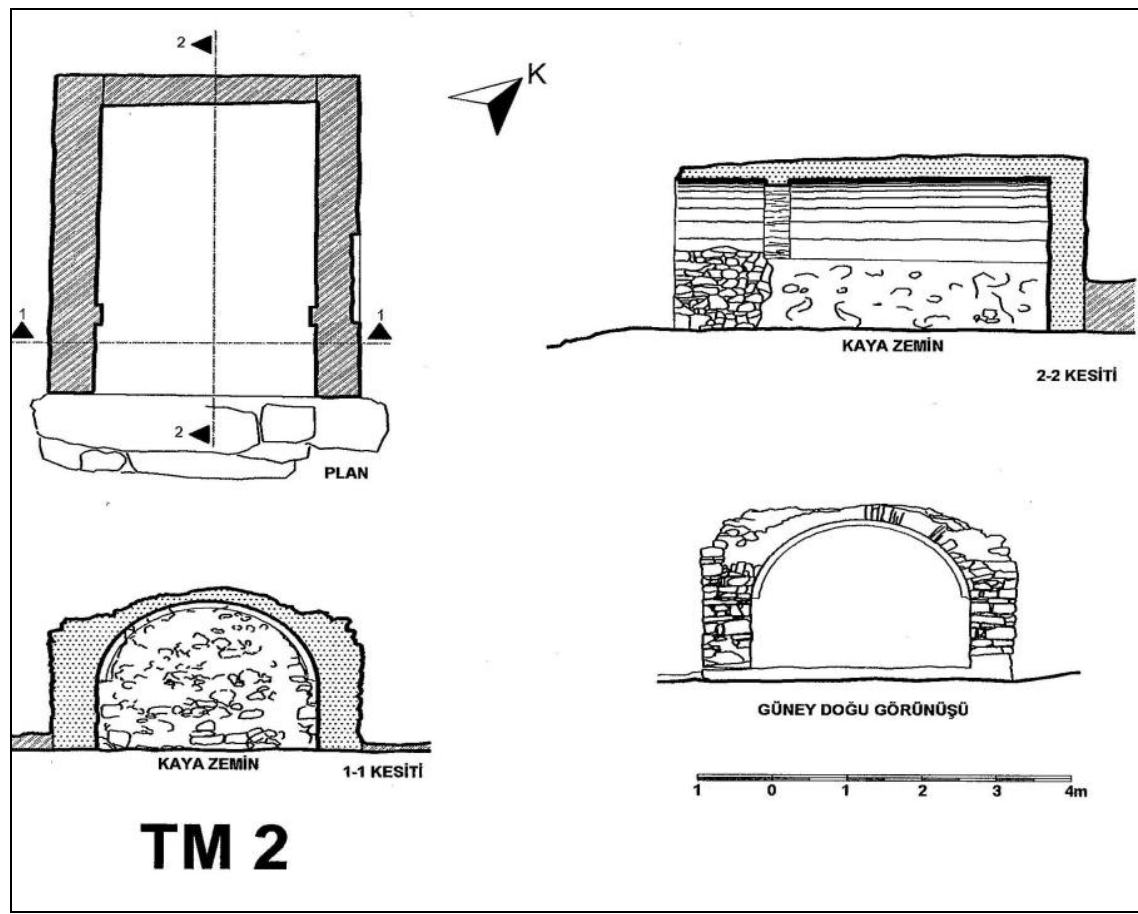

Fig.6; TM.1 Nolu Mezar Kesit, Plan ve Görünüş Çizimi 


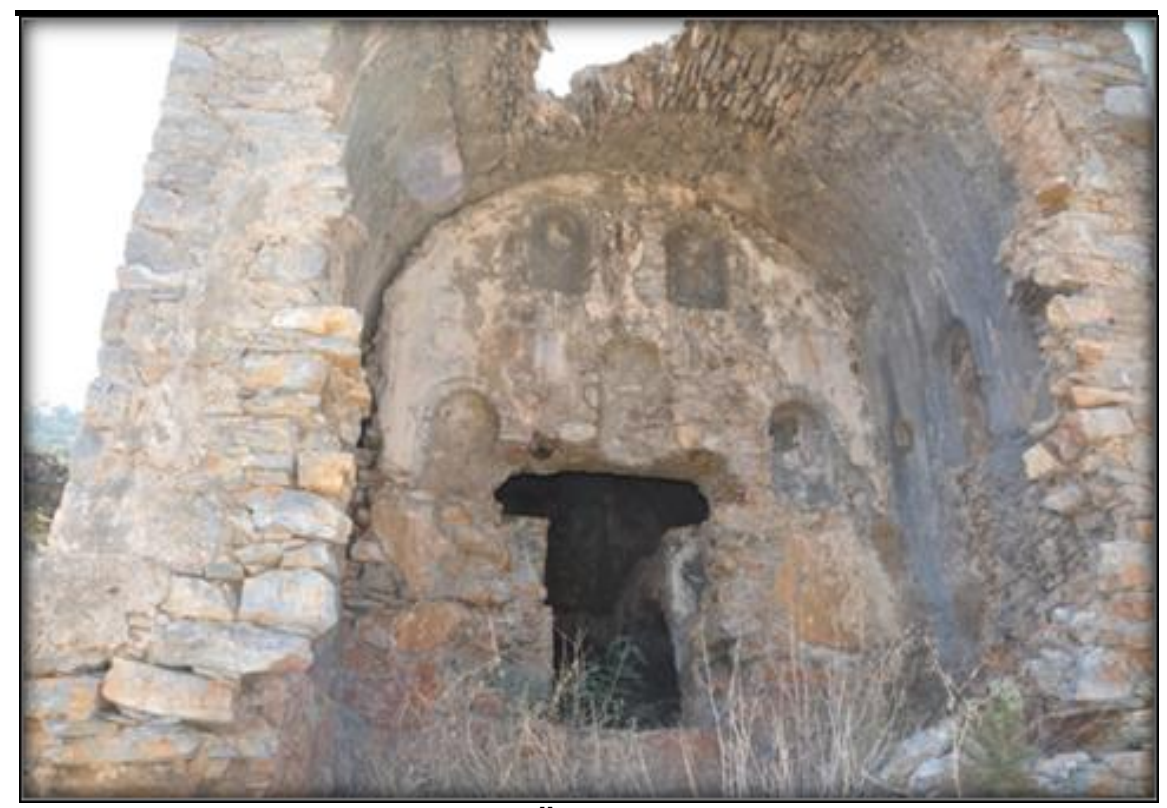

Fig.7; Anemurium Ön Odalı Tonozlu Mezar

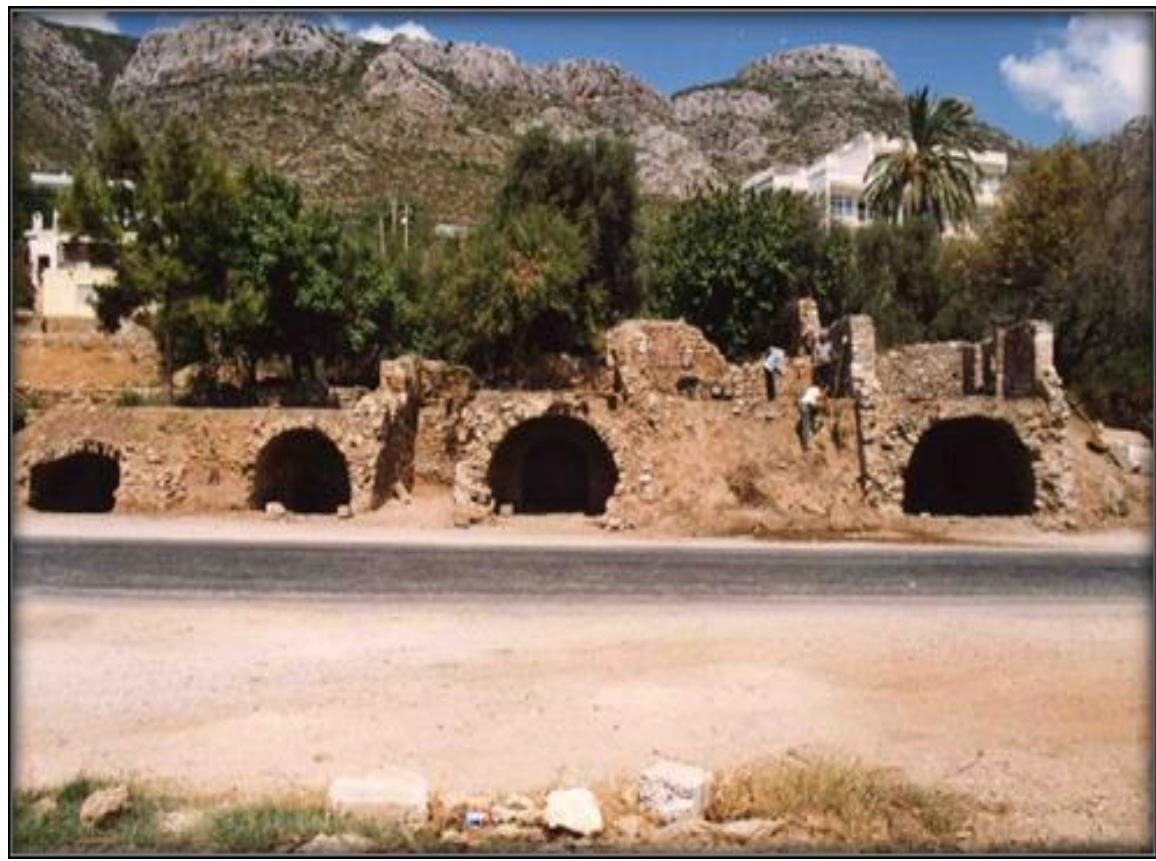

Fig.8; Kuzey Nekropolü Tonozlu Mezarlar Genel (Kelenderis Kazı Arşivi)

42 | Celal Bayar Üniversitesi Sosyal Bilimler Dergisi - Cilt: 14, Sayı: 1, Mart 2016 
Kelenderis Beşik Tonozlu Mezarları Üzerine Bir Değerlendirme

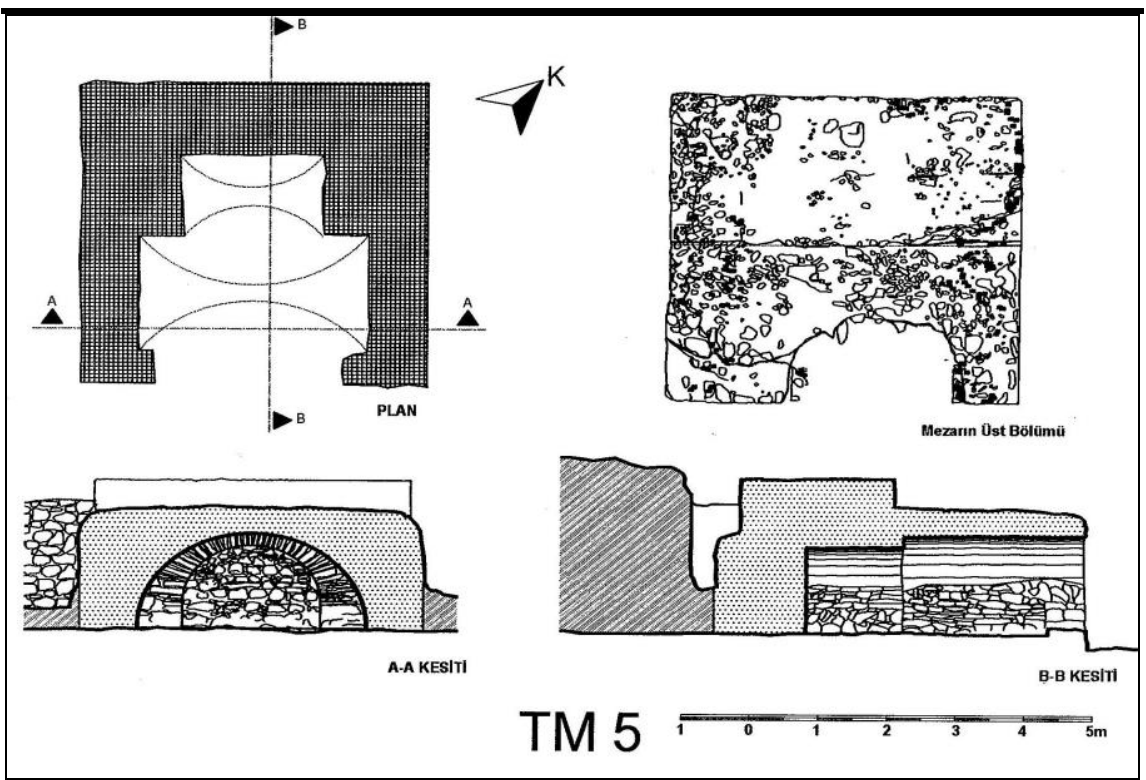

Fig.9; TM.5 Nolu Mezar Kesit, Plan ve Görünüş Çizimi

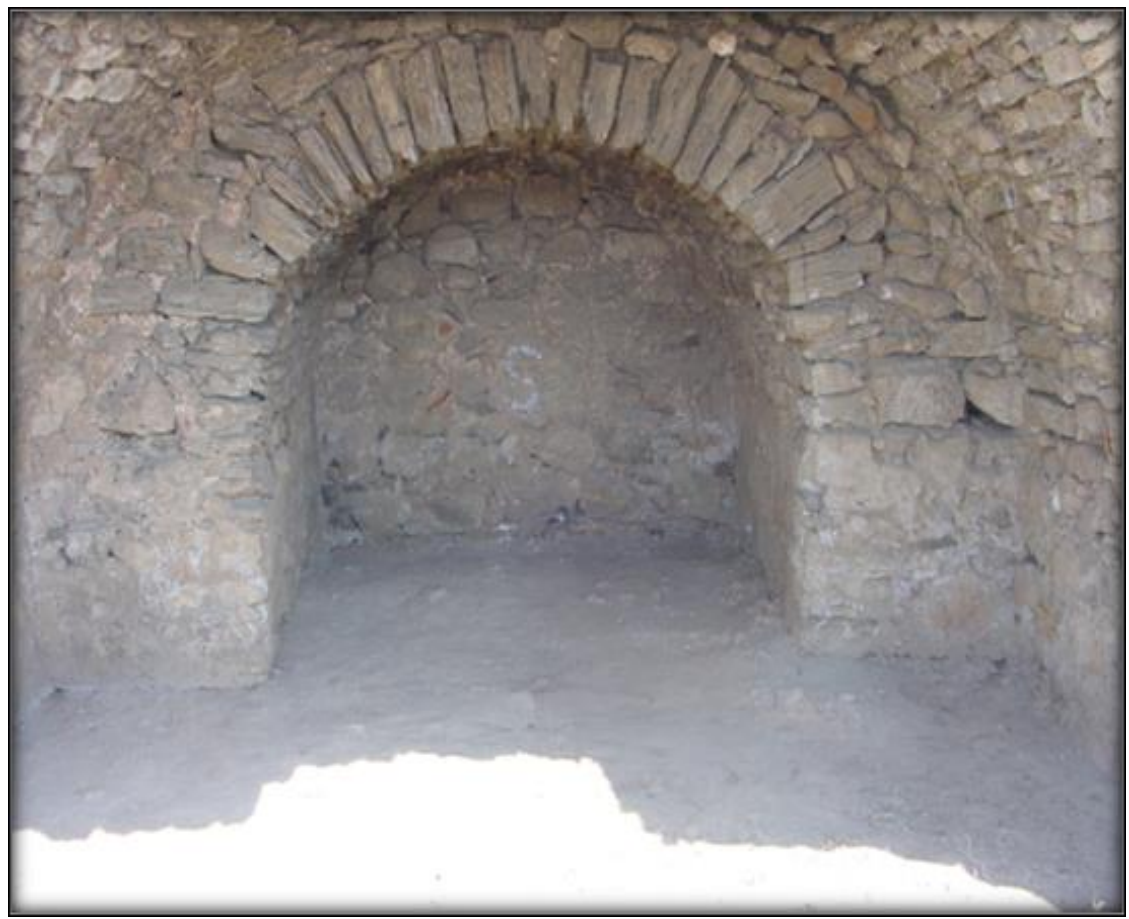

Fig.10; TM 5 Mezar Odası (Kelenderis Kazı Arşivi) 


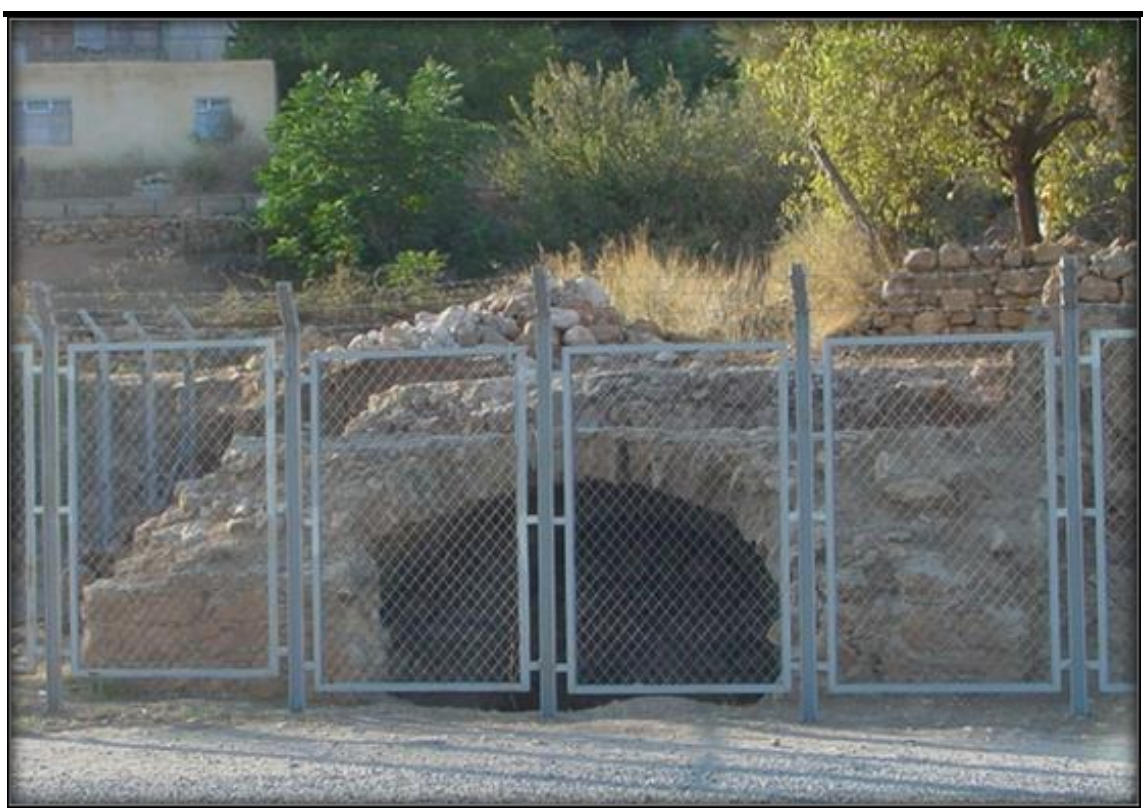

Fig.11; TM 5

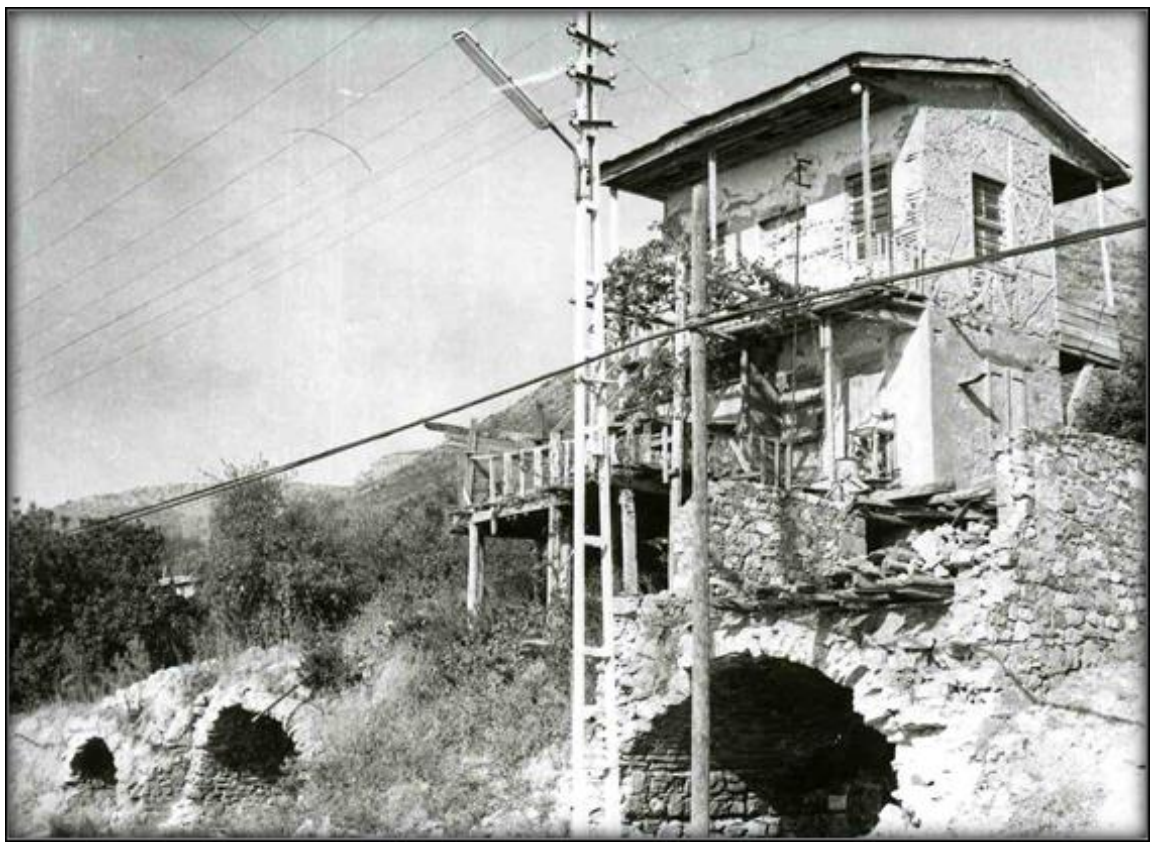

Fig.12; TM 7 ve 8 Nolu Mezarların Üzerindeki Ev (Kelenderis Kazı Arşivi) 


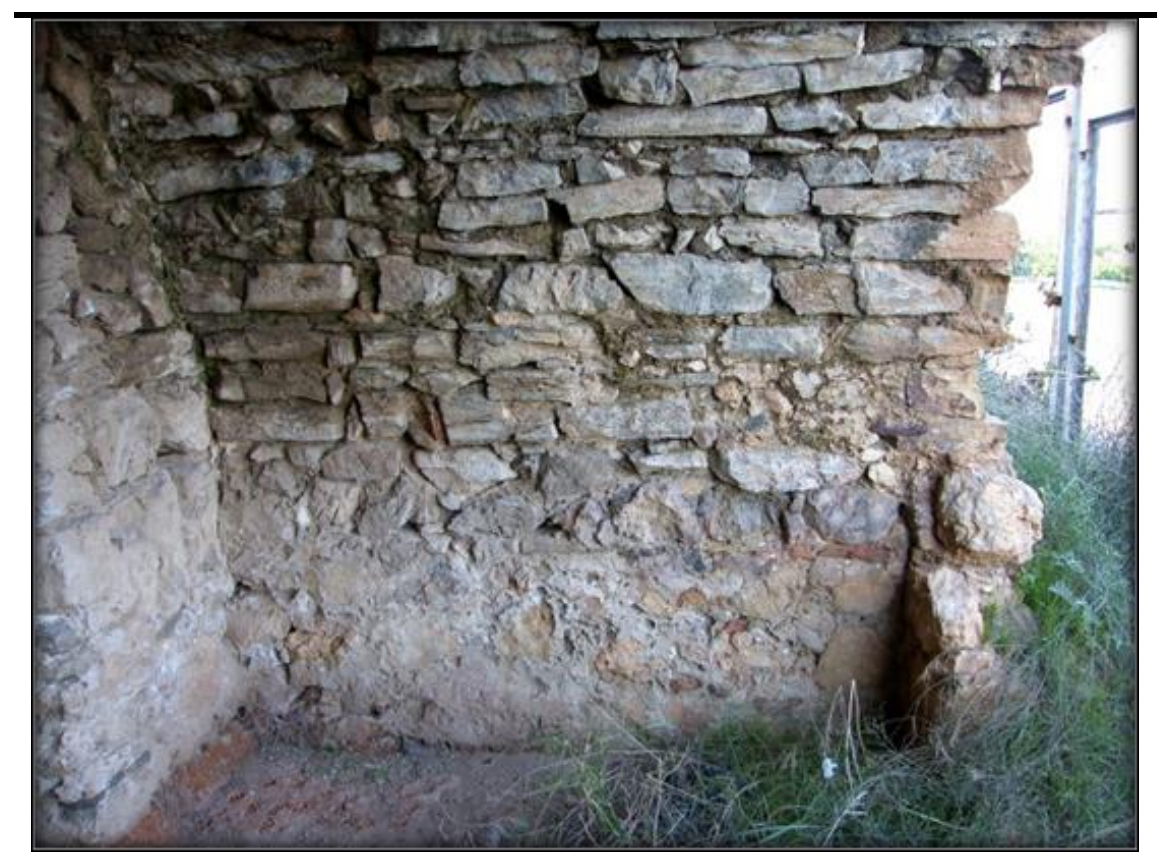

Fig 13; TM 7 Nolu Mezarın Mezar Odası Cephesindeki Duvar İzleri

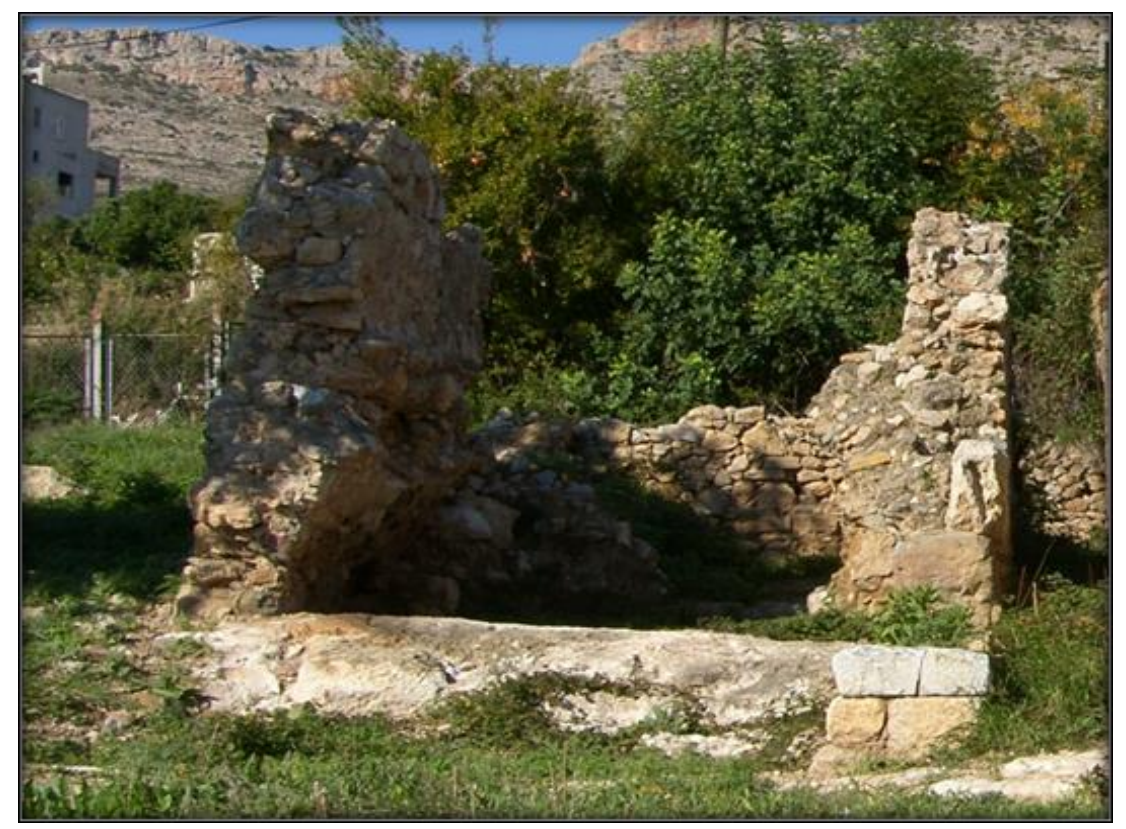

Resim 14; TM 3 Nolu Mezar

Beşeri Bilimler Sayısı $\mid \mathbf{4 5}$ 
46 | Celal Bayar Üniversitesi Sosyal Bilimler Dergisi - Cilt: 14, Sayı: 1, Mart 2016 